\title{
LIBERALISASI FEE ADVOKAT: ANTARA PERLINDUNGAN DAN KOMPETISI TERHADAP ADVOKAT INDONESIA
}

\author{
Stella Delarosa \\ email: delarosa_stella@yahoo.com
}

\begin{abstract}
This article analyses issues related to the implementation of fee liberalization by the ASEAN Economic Community (AEC) and its effect to the legal service business sector. Indonesian lawyers, as a consequence, will then have to compete with foreign legal service providers. It is assumed that through fair and transparent competition a more accountable business atmosphere can be created. However, a number of legal regulations at the national level establishes non-trade barriers, effectively obstructing the AEC' market liberalization project. The authors standing here is that the policy of protecting domestic lawyers or advocates should be rescinded and to that purpose Indonesia should amend the prevailing Law on Advocate.
\end{abstract}

Keywords:

fee Liberalization. Foreign Legal counsel. Lawyers-Advocate.

\begin{abstract}
Abstrak
Tujuan tulisan ini adalah menganalisis penerapan "liberalisasi fee" dalam konteks Masyarakat Ekonomi Asean (MEA) yang membuka pasar perdagangan jasa hukum dan sekaligus memaksa advokat Indonesia untuk turut berkompetisi dengan advokat asing di Indonesia. Diandaikan bahwa dengan kompetisi yang fair dan transparan akan tercipta peluang usaha yang akuntable. Namun demikian, sejumlah ketentuan dalam perundang-undangan nasional justru menghambat liberalisasi legal services di Indonesia. Titik tolak tulisan ini adalah sudah tidak masanya lagi Indonesia mempertahankan kebijakan 'melindungi advokat local-nasional' dari keterbukaan pasar MEA melalui ketentuan-ketentuan dalam perundang-undangan nasional terutama Undang-Undang Advokat.
\end{abstract}

Kata Kunci: liberalisasi Fee. Advokat Asing. Advokat yang Akuntable.

\section{Pengantar}

Arus Bebas Jasa (Free Flows of Services), termasuk Jasa Keuangan di dalamnya, telah dicanangkan oleh para pemimpin negara-negara ASEAN sebagai salah satu pilar utama dari pembentukan satu pasar tunggal dan basis produksi di kawasan Asia Tenggara, yang disebut sebagai Masyarakat Ekonomi ASEAN (ASEAN Economic Community atau AEC). Cetak biru AEC 2015 menyebutkan bahwa liberalisasi sektor jasa dimaksudkan untuk menghilangkan hambatan penyediaan jasa oleh pemasok ataupun pendirian jasa baru lintas negara di kawasan ASEAN dengan tetap tunduk pada regulasi domestik. 
Masuknya konsultan asing di Indonesia untuk dapat berpraktik jasa hukum di Indonesia, untuk saat ini diatur dalam Undang-Undang Nomor 18 Tahun 2003 Tentang Advokat (selanjutnya disebut UU Advokat). Pasal 23 UU Advokat, menyatakan:

(1) Advokat asing dilarang beracara di sidang pengadilan, berpraktik dan/atau membuka kantor jasa hukum atau perwakilannya di Indonesia.

(2) Kantor Advokat dapat mempekerjakan advokat asing sebagai karyawan atau tenaga ahli dalam bidang hukum asing atas izin Pemerintah dengan rekomendasi Organisasi Advokat.

(3) Advokat asing wajib memberikan jasa hukum secara cuma-cuma untuk suatu waktu tertentu kepada dunia pendidikan dan penelitian hukum.

(4) Ketentuan mengenai persyaratan dan tata cara memperkerjakan advokat asing serta kewajiban memberikan jasa hukum secara cuma-cuma kepada dunia pendidikan dan penelitian hukum diatur lebih lanjut dengan Keputusan Menteri.

Meskipun dalam UU Advokat ada larangan untuk berpraktik bagi advokat asing di Indonesia, namun menghadapi tantangan MEA tersebut, Pemerintah RI, melalui Departemen Perdagangan telah menawarkan perdana (initial offer) di sektor jasa untuk diliberalisasikan dalam kerangka WTO/MEA. Ketujuh sektor jasa yang ditawarkan RI tersebut antara lain pendidikan kejuruan; profesi kesehatan; kepemilikan perbankan kepada warga asing dari yang semula 49\% menjadi 51\%; diizinkannya profesi pengacara asing beroperasi di Indonesia; jasa konstruksi asing untuk membangun infrastruktur di Indonesia; pembangunan rumah sakit asing dengan kapasitas minimal mempunyai 400 tempat tidur; dan Ketujuh, perluasan izin keimigrasian ${ }^{1}$.

Asosiasi Persatuan Advokat Indonesia (Peradi), menyikapi tantangan MEA tersebut dengan, mengadakan pelatihan-pelatihan bagi advokat asing yang akan melakukan praktik di Indonesia. Tahun 2015 Peradi telah menyelenggarakan

\footnotetext{
1 Agus Budianto dan Gwendolyn I.U., Aspek Jasa Pelayanan Kesehatan dalam Prespektif Perlindungan Pasien, Bandung, Karya Putra Darwati, 2010, hlm., 181.
} 
pelatihan terhadap 11 peserta advokat asing, sementara pada tahun 2014, Peradi juga telah mengadakan pelatihan bagi sebanyak 58 advokat asing. ${ }^{2}$

Menjadi perhatian bersama adalah perihal perdagangan jasa (bukan perdagangan barang), karena perdagangan jasa ini memiliki potensi besar mengingat sektor jasa tidak menyedot banyak tenaga kerja (bukan padat karya), memiliki nilai tinggi, tidak merusak lingkungan. Di beberapa negara maju termasuk AS dan Uni Eropa, perdagangan jasa sudah menjadi perhatian yang cukup besar sejak dua dekade. Lihat saja keberadaan mega lawyer di dunia yang sebagian besar dikuasai oleh mereka termasuk pula jasa akuntan publik, arsitektur, medis dan rumah sakit. Sebagaimana yang dikatakan Bernard M. Hoekman dan Michel M. Kostecki³, "modern economies are service economies" (ekonomi modern adalah ekonomi jasa). Jasa-jasa seperti konsultan, konstruksi, transportasi, keuangan, pendidikan, profesional dan lain-lainnya mencakup 60 persen dari GDP (Gross Domestic Product) di Negara-negara OECD (Organisation for Economic Co-operation and Development).

Dalam upaya mendukung liberalisasi sektor jasa ini, terutama terkait lalu lintas atau perpindahan tenaga kerja terampil, negara-negara anggota ASEAN menandatangani MRA (Mutual Recognition Agreement) pada tanggal 19 November 2007. MRA ini menjadi sebuah hal mutlak yang dilakukan untuk mendukung liberalisasi sektor jasa yang berasaskan keadilan/fairness. MRA merupakan langkah awal yang penting untuk mempromosikan perpindahan tenaga kerja terampil. Setidaknya saat ini telah disepakati 8 MRA dan MRA Framework, yaitu (1) MRA untuk jasa teknik; (2) arsitek; (3) jasa perawatan; (4) praktisi medis; (5) praktisi gigi/dokter gigi; (6) jasa akuntan; (7) penyigian (surveying). Namun, dengan 7 initial offer yang dikeluarkan oleh Pemerintah Indonesia melalui Departemen Perdagangan tersebut di atas, kehadiran liberalisasi jasa konsultan hukum di Indonesia akan berdampak pada peningkatan profesionalisme

\footnotetext{
${ }^{2}$ http://www.hukumonline.com/berita/baca/lt57baf61d4b475/11-advokat-asing-ikuti-pelatihanyang-digelar-peradi

3 Bernard M.Hoekman and Michel M. Koestecki, The Political Economy of The World Trading System from GATT to WTO, Oxford, Oxford University Press, 1995, hlm., 127.
} 
konsultan hukum lokal, dengan salah satunya adalah penentuan fee kepada kliennya.

Pentingnya peranan sektor jasa, khususnya konsultan hukum asing di Indonesia dalam aktivitas ekonomi dan dalam perdagangan internasional disebabkan 4 (empat) alasan ${ }^{4}$, antara lain: 1) Perubahan terhadap metode atau cara berproduksi yang serba otomatis yang telah menyebabkan semakin pentingnya kebutuhan akan jasa dalam berproduksi; 2) Pemrosesan data yang serba modern (modern data processing) dan teknologi komunikasi telah membuat jasa semakin dapat diperdagangkan (tradable); 3) Kebutuhan jasa yang semakin meningkat dan dapat diperdagangkannya jasa telah membuat skala ekonomi kemungkinan melalui spesialisasi yang pada gilirannya telah menciptakan keuntungan dari perdagangan jasa; dan 4) Pertumbuhan perusahaan-perusahaan multinasional (multinational corporations) menyebabkan kebutuhan pemasok bisnis jasa yang bersifat multinasional semakin meningkat. 5

Dari keempat faktor tersebut di atas, konsultan hukum lokal (Indonesia) tidak mempunyai pilihan lain selain meningkatkan kerja dan kinerja dengan menguasai bahasa dan substansi hukum negara-negara Anggota ASEAN sebagai dampak dibukanya liberalisasi MEA. Oleh karena itu, liberalisasi pengenaan fee juga berpengaruh terhadap sektor jasa konsultan hukum ini. Dalam tulisan ini akan dideskripsikan mengenai liberalisasi fee konsultan hukum di Indonesia menghadapi MEA, yang sampai saat ini belum ada pengaturan yang jelas dan rigid dalam peraturan perundang-undangan, sehingga dampak lain yang muncul pun adalah adanya perlindungan hukum bagi klien, baik warga negara Indonesia ataupun klien dari anggota ASEAN lainnya.

\footnotetext{
4 Geza Feketekuty, Trade in Professional Services: An Overview, Chicago: The University of Chicago Legal Forum, 1986, hlm., 2-3.

5 Sebagai perbandingan, UNCTAD dalam laporannya mengatakan bahwa perkembangan perdagangan jasa yang semakin meningkat ditunjang oleh dua faktor utama. Pertama, kemajuan teknologi yang meningkatkan kemampuan jasa untuk dapat diperdagangkan (tradability) melintasi batas-batas wilayah negara. Kedua, kenaikan pendapatan yang disertai oleh pergeseran konsumsi dan produksi ke arah jasa-jasa. (Lihat: UNCTAD, Technology, Trade Policy and the Uruguay Round, United Nations, 1990, hlm. 92)
} 
Walaupun kita pahami bersama, bahwa pengenaan fee terhadap klien menjadi rahasia dapur masing-masing kantor advokat hukum di Indonesia, artinya bahwa pengenaan fee tersebut disesuaikan pengalaman atau tidaknya, besar kecilnya ruang usaha dan luas kecilnya jaringan yang dimiliki oleh sebuah kantor advokat. Namun menjadi tantangan bersama, ketika advokat asing mulai menjadi pesaing (kompetitor) bagi advokat Indonesia, tentunya menjadi permasalahan bagi advokat Indonesia adalah: pertama, penguasaan bahasa asing (Ingrris dan China) menjadi tantangan tersendiri, mengingat investor asing dikawasan ASEAN, khususnya Indonesia saat ini adalah Negara China ${ }^{6}$. Kedua, tentunya kepercayaan investor asing dalam memberikan kuasa dalam menyelesaikan masalah hukumnya, tidak lepas dari advokat dari negaranya. Ketiga, dukungan dana dan kepercayaan yang kuat dari investor dan masih lemahnya mental aparat penegak hukum akan suap, kolusi dan nepotisme, ibarat 'ada gula ada semut' dalam sistem peradilan di Indonesia.

Tulisan ini merupakan hasil studi yang dilakukan oleh Penulis dengan menggunakan metode penelitian normatif, yaitu mengkaji kualitas dari sebuah peraturan perundang-undangan tentang advokat dan sebuah kebijakan tentang masuknya advokat asing di Indonesia. Pendekatan yang digunakan adalah pendekatan konseptual, dengan mengangkat sebuah permasalah: dengan Indonesia menjadi anggota MEA, sehingga hadirnya advokat asing berparktik hukum di Indonesia menyebabkan secara langsung tercipta liberalisasi fee. Akankah liberalisasi fee ini dapat memberikan perlindungan terhadap advokat lokal (Indonesia) ataukah menjadi kompetitor yang memiliki dukungan dana yang kuat, pada akhirnya menguasasi pangsa pasar jasa konsultasi hukum di Indonesia?

\section{Tugas dan Fungsi Konsultan Hukum menurut UU Advokat dan Mekanisme Pengaturan Fee}

Konsultan hukum atau pengacara atau advokat mempunyai pengertian yang sama, oleh karenanya, sejak berlakunya UU Advokat, sebutan bagi seseorang

\footnotetext{
6 http://finance.detik.com/berita-ekonomi-bisnis/d-3110238/china-dominasi-investasi-asing-diri-senilai-rp-277-t
} 
yang berprofesi memberikan bantuan hukum secara swasta, yang semula terdiri dari berbagai sebutan, seperti advokat, pengacara, konsultan hukum, penasihat hukum adalah "advokat". Advokat adalah sebuah profesi yang memberikan jasa hukum (legal services). Idealisme profesi advokat bermetamorfosa sesuai dengan perkembangan zaman. Pada awal keberadaannya, profesi advokat dinamai sebagai officium nobile atau jabatan yang mulia. Penamaan itu berkaitan dengan aspek kepercayaan dari pemberi kuasa atau klien yang dijalankannnya untuk mempertahankan dan memperjuangkan hak-hak kliennya di forum yang telah ditentukan. $^{7}$ Berkaitan dengan hal tersebut, Yap Thiam Hien pernah berkata bahwa: "advokat adalah suatu profesi yang nobel dan penuh pengabdian kepada pihak yang lemah (tidak mengenal hukum)". ${ }^{8}$

Dengan berjalannya waktu, pengelolaan profesi advokat dirasa semakin komersial, hal ini berkaitan dengan perubahan tingkat profesionalitas dan terjadinya tuntutan spesialisasi advokat. Profesi advokat semakin menjadi lembaga tempat mencari keuntungan dan meninggalkan sifat-sifat nirlabanya, serta bukan lagi sebagai sarana perjuangan membela hak-hak kaum miskin. Berkaitan dengan hal ini, Satjipto Rahardjo sebagaimana dikutip oleh Daniel S Lev, menyatakan bahwa "banyak advokat kehilangan idealisme, merasa cukup puas dengan kesempatan, dan tidak banyak memikirkan keadaan negara atau keadaan masyarakat atau nasib profesinya sendiri. ${ }^{9}$

Dalam diri setiap advokat secara umum mungkin timbul keengganan untuk melaksanakan pemberian bantuan hukum cuma-cuma (pro-bono). Sifat dari profesi advokat adalah memberikan jasa hukum, artinya menjual kemampuanya di bidang hukum. Walaupun dilakukan karena perintah Undang-Undang, bukan

\footnotetext{
7 M.P. Pangaribuan, Advokat dan Contempt of Court Suatu Proses di Dewan Kehormatan Profesi, Jakarta, Penerbit Djambatan, 1996, hlm. 1.

8 Pujiono, Bantuan Hukum dalam Perspektif Tanggungjawab Negara, Copyright(C 2009 mitra hukum.org, All Right Reserved-Powered by nifiradamha, http://mitrahukum.org/konten.php?nama=0pini\&op=detail opini\&id=17.

9 Binziad Kadafi, Cs., Advokat Indonesia Mencari Legitimasi Suatu Studi Tentang Tanggungjawab Profesi Hukum di Indonesia xii, Kata Pengantar Daniel S. Lev, Jakarta, Pusat Studi Hukum dan Kebijakan, 2001.
} 
karena kepeduliannya atau penghargaannya terhadap hak ekonomi, sosial, dan budaya (Ekosob) ${ }^{10}$ masyarakat miskin. Jauh sebelum profesi advokat menjadi sangat komersial seperti sekarang ini, hasil penelitian Pusat Studi Hukum dan Kebijakan (PSHK) pada tahun 2001 membuktikan bahwa 62,6\% responden advokat yang diwawancarai menyatakan bahwa penyedia bantuan hukum probono seharusnya adalah pengadilan dengan anggaran penuh dari negara. ${ }^{11}$ Fakta tersebut dapat diartikan bahwa sebenarnya advokat cenderung enggan untuk melakukan bantuan hukum pro-bono. Bantuan hukum pro-bono harus dilakukan oleh negara dengan biaya negara. Berkenaan dengan kondisi seperti ini Marc Galenter, sebagaimana dikutip Satjipto Rahardjo12 menyatakan bahwa "profesi hukum lebih mementingkan fasilitas bisnis ketimbang berusaha untuk meringankan penderitaan manusia atau menolong manusia".

Hal ini akan mempengaruhi kualitas advokasi, karena sejatinya "konsentrasinya" berbeda, yang dianggap "mengganggu" tugas pokok advokat sebagai penyedia jasa hukum (legal services). Ditetapkannya pemberian bantuan hukum cuma-cuma merupakan kewajiban bagi advokat, hal ini tidak akan membuat para advokat menjalankan kewajibannya secara maksimal. Tidak seimbangnya jumlah pencari keadilan dengan advokat yang ada, disebabkan penyebarannya yang tidak merata di seluruh pelosok tanah air dan hanya terpusat di kota-kota berakibat masyarakat miskin yang sebagian besar berada di pelosok desa tidak mampu terlayani oleh jasa hukum advokat. Penyediaan bantuan hukum pro-bono dalam satu pintu yang dilaksanakan oleh advokat atau organisasi advokat telah mempersempit akses jasa hukum sehingga sebagai kebijakan

\footnotetext{
${ }^{10}$ Hak Ekosob merupakan instrumentasi hukum internasional hak asasi manusia yang telah ada sejak tahun 1966, namun baru diratifikasi oleh pemerintah Indonesia pada 1 Oktober 2005. Dengan diratifikasinya hak ekosob, tentu melahirkan sejumlah tantangan-tantangan dan konsekuensi tersendiri dalam upaya menghormati, melindungi, dan memenuhi hak-hak rakyat tersebut. R. Herlambang Perdana, Strategi Pemenuhan Hak Ekosob Di Jatim, Kompas 21 Februari 2006, hlm. 1.

11 Binziad Kadafi, Cs., supra catatan no. 10, hlm., 172-173.

12 Satjtipto Rahardjo, Sisi-Sisi Lain Hukum Di Indonesia, Jakarta, Penerbit Buku Kompas, 2003, hlm. 50-51.
} 
hukum tidak akan efektif, sebab sebelum berlakunya UU Advokat, pelayanan jasa hukum sangat bervariasi sehingga perluasan aksesnya sangat tinggi.

Pada saat menjalankan tugasnya seorang advokat memiliki hak dan kewajiban. Hak dan kewajiban seorang advokat adalah menjalankan tugas dan fungsinya sesuai Kode Etik Advokat Indonesia, Undang-Undang Advokat dan peraturan perundang-undangan lainnya yang mengatur tentang advokat. Hubungan antara advokat dan kliennya dipandang dari advokat sebagai officer of the court, yang mempunyai dua konsekuensi yuridis, sebagai berikut: ${ }^{13}$

1. Pengadilan akan memantau bahkan memaksakan agar advokat selalu menuruti ketentuan Undang-Undang atau kepantasan kepada kliennya, antara lain membela kliennya semaksimal mungkin sesuai dengan kewajiban fiduciary yang disandangnya.

2. Akan tetapi, di lain pihak, karena advokat harus membela kliennya semaksimal mungkin hampir-hampir tanpa kompromi, maka advokat haruslah hati-hati jika dia dihadapkan untuk membela kliennya semaksimal mungkin dengan tunduk sepenuhnya pada aturan hukum yang berlaku, seperti yang disebutkan dalam Canon 7 dari Code of Professional Responsibility dari advokat di Amerika Serikat bahwa advokat haruslah mewakili kliennya secara habis-habisan (zealous) dalam batas-batas hukum yang berlaku. "A lawyer should represent a client zealously within the bounds of the law". Jadi, meskipun advokat harus membela kepentingan kliennya secara habis-habisan, tetapi di lain pihak, sebagai officer of the court, dia tidak boleh melanggar aturan hukum yang berlaku, yang mungkin bertentangan dengan kepentingan kliennya itu.

Sebagai officer of the court, advokat harus tunduk dan patuh terhadap aturan yang ada di pengadilan. Lebih dari itu, advokat haruslah selalu bertingkat laku yang sesuai dengan kemuliaan dan kewibawaan pengadilan. Dia tidak boleh berperilaku tercela yang dapat mencoreng kewibawaan pengadilan tersebut. ${ }^{14}$ Pada pembukaan kode etik advokat menyatakan bahwa profesi advokat adalah

13 Munir Fuady, Profesi Mulia, Bandung, PT Citra Aditya Bakti, 2005, hlm., 33-34. 14 Id. 
suatu profesi terhormat (officium nobile). Kode etik mengenai advokat itu tidak dimaksudkan untuk mengurangi atau menghambat kemandirian profesi, yang punya kewajiban mulia atau terpandang (officium nobile). Sebaliknya, kode etik advokat merupakan hukum tertinggi dalam menjalankan profesi, yang menjamin dan melindungi namun membebankan kewajiban kepada setiap advokat untuk jujur dan bertanggung jawab dalam menjalankan profesinya baik kepada klien, pengadilan, teman sejawat, negara atau masyarakat, dan terutama kepada dirinya sendiri. ${ }^{15}$

Kode etik advokat harus dipatuhi oleh setiap advokat, di dalam kode etik tersebut terdapat peraturan yang mewajibkan para advokat untuk menjaga rahasia dengan kliennya. Seperti yang dikutip dari Kode Etik Advokat Pasal 4 huruf h: "Advokat wajib memegang rahasia jabatan tentang hal-hal yang diberitahukan oleh klien secara kepercayaan dan wajib tetap menjaga rahasia itu setelah berakhirnya hubungan antara Advokat dan klien itu."

Jasa advokat akan diberi imbalan berupa legal fee atau honorarium. Honorarium yang diterima seorang advokat tidak memiliki batasan, yang artinya honorarium advokat tidak ada ditentukan jumlahnya dalam undang-undang maupun kode etik advokat. Nilai besarnya honorarium setiap advokat berbedabeda meskipun atas suatu kasus atau perkara yang mirip sama. Yang terpenting ada persetujuan yang jelas antara advokat dengan calon kliennya, baik menyangkut fee maupun success fee yang akan diterima advokat. Seorang calon klien berhak untuk mengundurkan diri dari pembicaraannya, jika ia merasa tidak akan sanggup dapat membayar fee kepada seorang advokat. Demikian pula advokat berhak untuk menentukan sikapnya menyangkut fee yang akan diterima dari calon kliennya.

Dalam pasal 21 Undang-Undang Advokat disampaikan bahwa Advokat berhak menerima Honorarium atas Jasa Hukum yang telah diberikan kepada Kliennya dan Besarnya Honorarium atas Jasa Hukum ditetapkan secara wajar

15 Pembukaan Kode Etik Advokat. 
berdasarkan persetujuan kedua belah pihak. Seperti diketahui, pengaturan honorarium advokat sebagaimana tertuang dalam Pasal 21 UU Advokat tersebut dapat dikatakan menjadi landasan yuridis keabsahan legal service fee. Namun bila tidak diatur secara tegas, sebagai contoh penasehat hukum yang menerima pembayaran jasa hukum (legal service fee) dari terdakwa tindak pidana pencucian uang dapat pula diancam pidana berdasarkan ketentuan Pasal 6 Undang-Undang Nomor 25 Tahun 2003 tentang Tindak Pidana Pencucian Uang. Pasalnya, dalam hubungan profesional antara advokat dan klien, terdapat suatu hubungan yang sangat dekat sehingga, advokat patut menduga harta yang dimiliki kliennya adalah hasil tindak pidana. Namun, adanya ketentuan kode etik kerahasiaan advokat terhadap klien, tidak memungkinkan para advokat melaporkan harta yang dimiliki kliennya atas dugaan tidak pidana. Apabila dibandingkan di Amerika, lawyer di Amerika khawatir ketika mendampingi klien bila tidak ada kepastian akan asal muasal harta kekayaan untuk membayar jasa mereka. ${ }^{16}$

Berkenaan dengan keabsahan menerima legal service fee dari klien yang diduga melakukan tindak pidana pencucian uang, lawyer atau advokat di negeri Paman Sam itu sempat mengalami dilema. Oleh karena itu, otoritas setempat selanjutnya membuat suatu ketentuan mengenai pembayaran jasa hukum bagi para advokat yang menjadi penasehat hukum terdakwa tindak pidana pencucian uang. Menjawab persoalan ini, pengadilan Amerika berupaya menyelesaikannya dengan mengeluarkan semacam putusan sela sebelum proses peradilan, dengan demikian terdapat sebuah pemisahan aset yang harus disisihkan untuk pembayaran lawyer17. Ari Yusuf membagi fee advokat ke dalam tiga klasifikasi yaitu: Lawyer fee, yang umumnya dibayar di muka sebagai biaya profesional sebagai advokat; Operational fee, yang dikeluarkan klien selama penanganan perkara oleh advokat, dan Success fee, prosentasenya ditentukan berdasarkan

\footnotetext{
16 Yenti Gamasih, hukum online: 23 Feb 2005 dalam Jurnal Yustlsla Edisi Nomor 75 Sept-Desember 2008 "Legal Service Fee Penasehat Hukum Terdakwa Money Laundering Dalam Sinkronisasi UU Advokat Dan UU Tindak Pidana Pencucian Uang” oleh Muhammad Rustamaji, hlm., 55. 17 Id.
} 
perjanjian antara advokat dengan klien. Success fee dikeluarkan klien saat perkaranya menang, tapi jika kalah, advokat tidak mendapat success fee. ${ }^{18}$

Di sisi lain, bahwa sebuah kantor hukum di Jakarta menetapkan komponen biaya jasa hukum untuk kasus perceraian sebagai berikut: honorarium advokat, biaya transport, biaya akomodasi, biaya perkara, biaya sidang, dan biaya kemenangan perkara (success fee) yang besarnya antara 5-20 persen. ${ }^{19}$

Dari uraian di atas kiranya dapat disimpulkan bahwa fee advokat yang dihitung berdasarkan prosentase adalah komponen success fee. Sebagaimana dijelaskan Ari Yusuf besarnya success fee ditentukan berdasarkan kesepakatan atau perjanjian antara advokat dengan klien. Jadi, jika Anda sebagai klien keberatan dengan success fee sebesar 40 persen maka Anda dapat menegosiasikan jumlah tersebut dengan advokat Anda. Apalagi berdasarkan hasil penelitian PSHK rata-rata besarnya success fee jasa hukum di Jakarta yaitu antara 5-20 persen.

Namun, itu bukan berarti jika besarnya success fee lebih dari 20 persen adalah tidak wajar, karena hal tersebut juga ditentukan dari tingkat kesulitan perkara yang ditangani. Sehingga untuk menentukan apakah nilai 40 persen tersebut wajar atau tidak, tentu harus dilihat kasus perkasus. Penting untuk dipahami bahwa klien berhak meminta informasi secara terbuka dari advokat mengenai perhitungan honorarium, komponen-komponennya dan cara pembayarannya. ${ }^{20}$

Dalam Kode Etik Advokat tersebut disampaikan bahwa dalam menentukan besarnya honorarium Advokat wajib mempertimbangkan kemampuan klien dan Advokat tidak dibenarkan membebani klien dengan biaya-biaya yang tidak perlu. Dengan demikian batasan terhadap honor yang diterima oleh Advokat dibatasi dalam ketentuan perundang-undangan yaitu ditetapkan secara wajar berdasarkan

\footnotetext{
${ }^{18}$ Ari Yusuf Amir: Jangan Gadaikan Reputasi Advokat dengan Membohongi Klien, http://www.hukumonline.com/berita/baca/hol19761/ari-yusuf-amir-jangan-gadaikanreputasi-advokat-dengan-membohongi-klien (terakhir diakses, 13 September 2016).

19 Advokat Indonesia Mencari Legitimasi yang diterbitkan Pusat Studi Hukum dan Kebijakan Indonesia, hlm. 315.

${ }^{20}$ http://www.hukumonline.com/klinik/detail/lt4f0acb102f02e/fee-yang-wajar-untuk-advokatsuccess-fee- (terakhir diakses, 16 September 2016).
} 
kesepakatan kedua belah pihak dan wajib mempertimbangkan kemampuan klien dan menghindari pembebanan biaya yang tidak perlu sebagaimana diatur dalam Kode Etik Advokat.

\section{Liberalisasi Fee Advokat menghadapi MEA: Antara Perlindungan dan Kompetisi Jasa Advokat}

Menurut Kamus Besar Bahasa Indonesia, liberalisasi dalam pengertiannya dimaknai sebagai sebuah proses (usaha dan sebagainya) untuk menerapkan paham liberal dalam kehidupan (tata negara dan ekonomi). Pengertian lain liberalisasi (perdagangan) adalah suatu keadaan dimana perusahaan dan individu bebas untuk menjual barang atau jasa melampaui batas wilayah negaranya. ${ }^{21}$ Dalam hal ini berarti termasuk di dalamnya adalah kebebasan untuk mendirikan perusahaan di negara lain dan bagi individu untuk bekerja di negara lain.

Hadi Soesastro, dan kawan-kawan ${ }^{22}$, menyatakan bahwa liberalisasi adalah menyamaratakan proses produksi barang dan jasa antara negara, artinya, dengan liberalisasi tidak ada lagi hambatan yang dibuat oleh suatu negara dalam melakukan suatu transaksi perdagangan dengan negara lainnya. Negara-negara di dunia atau yang terlibat langsung dalam perdagangan bebas mempunyai hak untuk menjual produk baik barang ataupun jasa terhadap negara lain tanpa harus dibebani oleh batasanbatasan pajak atau bea masuk.

Demikian juga dalam halnya liberalisasi sektor barang dan jasa di kawasan MEA, masing-masing anggota MEA akan dengan bebas tanpa adanya hambatan dari negaranya dalam melakukan produksi, pemasaran dan kebijakan barang dan/atau jasanya dalam suatu kawasan perdagangan. Sebagaimana halnya dalam kawasan WTO, di mana Indonesia menjadi anggota World Trade Organization (WTO) melalui Undang-Undang No. 7 Tahun 1994 tentang Pengesahan Agreement Establishing the World Trade Organization (Persetujuan Pembentukan Organisasi

\footnotetext{
${ }^{21}$ http://id.wikipedia.org/wiki/Perdagangan_bebas, diunduh pada 10 November 2016

22 Hadi Soesastro, et., all, Pemikiran dan Permasalahan Ekonomi di Indonesia dalam Setengah Abad Terakhir: Deregulasi dan Liberalisasi Ekonomi, Jogjakarta, Kanisius, 2005, hlm., 433.
} 
Perdagangan Dunia). WTO sendiri mulai beroperasi secara resmi pada tanggal 1 Januari 1995.

Adanya liberalisasi merupakan arus pemikiran umum yang muncul sebagai respon perkembangan dunia yang sangat dinamis, progresif dan berkarakter multidimensi. Karakter multidimensi ini berdasarkan pada sebuah teori yang dikemukakan oleh Talcott Parson yang dikenal dengan social cybernatic. Teori ini mengatakan bahwa masyarakat bukan persamaan tetapi dapat dikatakan sebagai masyarakat jika mereka dapat menintegrasikan suatu perbedaan-perbedaan ${ }^{23}$.

Proses perkembangan liberalisasi dalam fase awal akan mempengaruhi orientasi ekonomi dan struktur politik hingga menjalar pada struktur sosial. Pada fase terakhir, kondisi ini akan merombak tatanan budaya suatu komunitas tertentu. Lebih lanjut dikatakan, masyarakat saling terkait dalam menjalankan suatu hubungan atau interaksi, sehingga kondisi satu merupakan prasyarat dalam kehidupan. Dalam liberalisasi sektor jasa dalam MEA, yang mana satu negara memiliki karakter yang berbeda dengan negara lain, namun dalam kondisi tertentu, perbedaan-perbedaan tersebut harus disamakan untuk satu pasar tunggal, maka teori Parson tersebut sebanding luruh dengan teori Adam Smith. Menurut teori ini, pembagian kerja atau spesialisasi dianggap sebagai kunci pertumbuhan ekonomi yang terus menerus. Pemikiran yang demikian menghendaki adanya dukungan solid dari pasaran barang produksi dengan manifestasinya perluasan wilayah sebagai dalih untuk memperluas pasar, bahkan dengan bantuan pemerintah sekalipun ${ }^{24}$.

Munculnya kebebasan dalam melaksanakan perdagangan antar negara atau disebut dengan perdagangan internasional termotivasi oleh paham dan teori yang dikemukakan oleh Adam Smith, yang menyatakan bahwa kesejahteraan masyarakat suatu negara justru akan semakin meningkat, jika perdagangan internasional dilakukan dalam pasar bebas dan intervensi pemerintah dilakukan

23 Talcott Parson Today, His Theory and Legacy Contemprorary Sociology, xlvii-xlix Edited: A. Javier Trevino, (England, Rowman\&Litlle Field Publishers, 2001)

24 Mahmul Siregar, Perdagangan Internasional dan Penanaman Modal, Medan; Sekolah Pascasarjana Universitas Sumatera Utara, 2005, hlm., 43. 
seminimal mungkin. Apabila ditinjau dari perspektif liberalisasi jasa advokat pada MEA, liberalisasi menekankan pada platform kebebasan individu atau peran rakyat secara aktif, dengan peran negara yang negatif dalam transaksi perdagangan. Meniadakan hambatan (barrier to entry) menuju liberalisasi, itulah yang menjadi kata kuncinya.

Terdapat dua contoh yang menjadi hambatan yang kemungkinan terjadi dalam perdagangan jasa di ASEAN adalah sebagai berikut: Pertama, perbedaan aturan dan persyaratan bagi perusahaan-perusahaan asing yang berasal dari sesama anggota ASEAN. Satu sisi ingin menciptakan perusahaan-perusahaan di ASEAN yang memiliki keunggulan kompetitif, di sisi lain ada hambatan sebagai sarana proteksi perusahaan dalam negeri; Kedua, persyaratan bagi perusahaan asing untuk menggunakan sumber daya manusia dari negara anggota ASEAN sebesar prosentase tertentu atau kewajiban untuk melakukan joint venture dengan sebuah perusahaan di negara anggota ASEAN.

Dari sepuluh negara anggota ASEAN, delapan negara anggota telah membuat komitmen dalam perdagangan jasa seperti berikut ini :25 1) Business Services. Professional services yang mencakup, Legal services (Indonesia, Viet Nam); Accounting services (Malaysia, Myanmar, Philippina); Taxation services (Malaysia); Architectural services (Brunei, Indonesia, Malaysia, Myanmar); Engineering services (Indonesia, Malaysia, Myanmar, Philippina, Thailand); Urban planning services (Indonesia, Malaysia, Thailand); Landscape architectural services (Malaysia, Myanmar, Thailand, Philippina); Veterinary services (Malaysia); and Interior design services (Philippina); Computer and related services (Indonesia, Malaysia, Myanmar, Thailand); dan Research and development services (Indonesia).

Nomor 2 sampai nomor 8 tidak kami uraikan, karena kami fokus pada legal services di kawasan ASEAN. Jasa hukum (legal service) masuk dalam ruang lingkup jasa profesional (professional services) yang merupakan bagian dari jasa bisnis (business services). Hambatan yang paling utama dalam perdagangan jasa hukum

\footnotetext{
25 Sebagai catatan, bahwa Laos dan Myanmar belum menjadi anggota WTO.
} 
ini adalah kualifikasi, standarisasi dan lisensi bagi para advokat (bisa dalam bentuk investor melalui law firm atau melalui orang perorangan/natural person) dari masing-masing organisasi profesi negara anggota ASEAN yang hendak menjual jasa di negara anggota ASEAN.

Dalam pertemuannya di Istambul bulan Juni 2001, Dewan IBA (International Bar Association) memberikan rekomendasi tentang standard dan kriteria yang harus diterapkan oleh anggota WTO yang telah melakukan komitmen akses pasar berkaitan dengan jasa hukum berdasarkan Artikel XVI GATS yang dimaksudkan untuk memberikan pengakuan kualifikasi profesional dari orang-orang yang diberikan lisensi atau kewenangan untuk mempraktekkan hukum di wilayah negara anggota WTO lainnya (home jurisdiction) dengan tujuan untuk memberikan lisensi atau kewenangan terhadap orang-orang tersebut untuk mempraktekkan hukum di wilayah negara anggota untuk mengakui kualifikasi tersebut (host jurisdiction). Dokumen tersebut juga memasukkan rekomendasirekomendasi yang berhubungan dengan muatan-muatan perjanjian pengakuan bersama seperti yang diatur dalam Artikel VII GATS.

Dalam rekomendasi ini diyakini bahwa satu hambatan utama terhadap pengakuan tersebut adalah kekawatiran bahwa pengakuan yang dilakukan oleh negara anggota terhadap kualifikasi advokat yang berpraktek di wilayah satu atau lebih negara anggota yang lain secara otomatis mewajibkan untuk tidak melakukan diskriminasi, seperti yang ditetapkan dalam Artikel II GATS berkaitan dengan advokat yang memiliki kualifikasi untuk menjalankan praktek di wilayah semua negara anggota. Kekhawatiran ini cenderung mengabaikan klausula MFN dengan maksud tidak menciptakan liberalisasi. IBA sangat yakin bahwa karakteristik khusus dan peran profesi hukum serta perbedaan-perbedaan penting dalam sistem hukum dan sistem pengaturan profesional seperti yang tercermin dalam Background Note of July 6, 1998 on Legal Services ${ }^{26}$.

26 WTO Council for Trade in Services, Legal Services, Background Note by the Secretariat, S/C/W/43, 6 Juli 1998. 
Masalah mendasarnya adalah ada pada ranah praksis dan teknis. Contoh saja di Singapura, menurut Singapore Legal Profession Act 1997, untuk bisa diangkat menjadi advokat di Singapura harus lulus sarjana hukum (bachelor of law) dari Universitas Malaya Singapura, University of Singapore atau National University of Singapore. Menteri Kehakiman setelah berkonsultasi dengan Dewan Pendidikan Hukum (Board of Legal Education) menentukan kualifikasi, pendidikan dan pelatihan untuk orang-orang yang dikualifikasikan sebagai advokat

Bagi advokat asing yang ingin memperoleh ijin praktek harus memperoleh persetujuan dari Attorney General. Apabila ijin tersebut disetujui maka advokat asing memiliki hak :

1. Advokat asing yang dipekerjakan oleh, atau partner, atau direktur, dari sebuah joint law venture dapat mempraktekkan hukum Singapura sebagai partner, direktur, atau pegawai dari joint law venture tersebut. Dia juga mendapatkan kompensasi pengeluaran dan pembayaran atas jasanya apabila terdaftar untuk mempraktekkan hukum Singapura oleh Attorney General.

2. Advokat asing yang terdaftar untuk berpraktek hukum di Singapura tidak dapat mewakili pihak manapun di pengadilan, badan arbitrase, atau peradilan lainnya di Singapura kecuali advokat asing tersebutn diijinkan untuk melakukannya

3. Attorney General berdasarkan diskresinya dapat menyetujui permohonan pendaftaran seorang advokat asing untuk mempraktekkan hukum Singapura selama periode tertentu yang dianggap layak oleh Attorney General kecuali dalam kondisi di mana Attorney General mensyaratkan agar advokat asing yang bersangkutan memenuhi modul pelatihan terlebih dahulu.

Dalam joint law venture, firma hukum yang sudah terdaftar memiliki hak untuk menyediakan jasa hukum sesuai kualifikasinya dalam bidang hukum tertentu yang telah disepakati sebelumnya oleh kedua belah pihak. Firma hukum asing juga berhak melakukan penagihan terhadap kliennya serta dapat 
memberikan nasehat dan konsultasi hukum yang berkenaan dengan hukum Singapura. Advokat asing yang tergabung dalam joint law venture ini lebih menikmati hak-hak yang penuh (hampir sama dengan advokat lokal).

Sementara pada kerjasama yang berbentuk formal law alliance, tidak ada pembatasan jumlah firma hukum yang dapat tergabung di dalamnya. Advokat asing yang tergabung dalam formal law alliance dapat menyiapkan dokumen transaksi yang berkaitan dengan peraturan dari beberapa yurisdiksi negara, tapi tidak boleh memberikan opini hukum yang berkaitan dengan hukum Singapura. Opini hukum harus diberikan oleh advokat Singapura yang memiliki ijin praktek. Bagi advokat asing dalam formal law alliance hanya memiliki ijin dalam waktu tertentu dan juga memiliki kewajiban untuk mengikuti kursus-kursus tertentu. Berkaitan dengan etika profesi, seperti yang diatur dalam Profession Act, advokat asing yang memperoleh ijin praktek di Singapura harus tunduk pada aturan etika profesional. Apabila perbuatan advokat asing merugikan klien atau masyarakat maka pihak yang dirugikan dapat mengadu kepada Attorney General.

Di Indonesia kehadiran dan peran advokat asing telah secara tegas diatur dalam Pasal 23 Undang-Undang Advokat, sebagaimana sudah disebutkan diatas. Namun, kantor advokat dapat mempekerjakan advokat asing sebagai karyawan atau tenaga ahli dalam bidang hukum asing atas ijin pemerintah dengan rekomendasi organisasi advokat. ${ }^{27}$ Kehadiran pengacara atau advokat asing di Indonesia bukanlah hal baru di Indonesia. Jauh sebelum awal tahun 2005, Asosiasi Advokat Indonesia (AAI) pernah meminta advokat Monsanto Company-Barry Irwin, Damian Adams dan Ken Cheung- segera ditangkap dan diproses hukum. Alasannya, ketiga advokat Monsanto itu tidak tercatat di dalam buku daftar advokat, dan tidak memiliki nomor induk advokat. Apakah ini yang disebut dengan melindungi advokat lokal (Indonesia), dengan melakukan penangkapan terhadap advokat asing?.

27 Lihat: Pasal 23 Undang-Undang Nomor 18 Tahun 2003 tentang Advokat. 
Dalam perkembangan selanjutnya, Departemen Hukum dan HAM selaku pemantau sepak terjang advokat asing yang datang seiring dengan arus globalisasi tidak mempersempit lapangan yang sudah kian sempit. Ketentuan itu tertuang dalam Keputusan Menteri Hukum dan HAM No. M.11-HT.04.02 Tahun 2004 tentang Persyaratan dan Tatacara Memperkerjakan Advokat Asing serta Kewajiban Memberikan Jasa Hukum Secara Cuma-Cuma Kepada Dunia Pendidikan dan Penelitian Hukum.

Salah satu butir Keputusan Menteri Hukum dan HAM tersebut mengatur mengenai permohonan penggunaan advokat asing untuk menjadi karyawan atau tenaga ahli pada kantor advokat Indonesia. Pasal 2 ayat (4) Kepmenhum merumuskan: "Permohonan penggunaan advokat asing untuk menjadi karyawan atau tenaga ahli di bidang hukum asing pada kantor advokat Indonesia, diajukan oleh kantor advokat yang akan memperkerjakan advokat asing." Rumusan baru tersebut agak berbeda dibandingkan Kepmenhum No. M.01.04.02 Tahun 1997. Dalam ketentuan yang lama, permohonan penggunaan advokat asing bisa dilakukan berdasarkan permohonan sendiri, atau berdasarkan kerjasama antara kantor konsultan hukum Indonesia dengan suatu kantor konsultan hukum asing.

Berdasarkan Kepmenhum tahun 2004 tersebut, surat permohonan penggunaan advokat asing diajukan kepada Menteri Hukum dan HAM dengan tembusan kepada Menteri Tenaga Kerja dan Transmigrasi, Direktur Jenderal Administrasi Hukum Umum (AHU) Depkum dan HAM, serta Direktur Perdata pada Ditjen Administrasi Hukum Umum. Sedangkan ketentuan sebelumnya, tembusan permohonan cukup disampaikan kepada Menkertrans dan Dirjen Hukum dan Perundang-undangan. Persyaratan yang harus dilengkapi sejalan dengan surat permohonan itu meliputi: rekomendasi dari organisasi advokat, perjanjian kerja antara kantor advokat Indonesia dan advokat asing yang dilegallisir notaris, serta data lengkap dari advokat asing. Data (dokumen) lengkap dari advokat asing terdiri dari daftar riwayat hidup, fotocopi ijasah yang dilegalisir Kedutaan Besar RI di negara advokat asing berasal, surat keterangan sebagai 
pengacara aktif yang dikeluarkan oleh lembaga resmi yang dilegalisir oleh Kedubes RI di negara advokat asing berasal.

Sampai saat ini, Kementerian Hukum dan HAM sudah terdapat sebanyak 47 advokat asing bekerja di kantor advokat lokal, yang sampai saat ini keberadaan 47 advokat asing tersebut dimaknai sebatas tenaga asing biasa yang diatur dalam Keputusan Presiden RI No. 75 Tahun 1995 tentang Pembatasan Penggunaan Tenaga Kerja Warga Negara Pendatang. Kapasitas dan kapabilitas advokat asing tersebut sebatas memberikan pendapat hukum dalam praktik hukum bisnis, bukan sebagai kuasa hukum yang berpraktik di peradilan 28 .

Sebagaimana sudah kami paparkan dalam sub bab latar belakang tersebut di atas, bahwa Peradi, juga telah menyikapi tantangan MEA tersebut dengan, mengadakan pelatihan-pelatihan bagi advokat asing yang akan melakukan praktik di Indonesia. Tahun 2015 Peradi telah menyelenggarakan pelatihan terhadap 11 peserta advokat asing, sementara pada tahun 2014, Peradi juga telah mengadakan pelatihan bagi sebanyak 58 advokat asing. Artinya, Pemerintah Indonesia telah mensikapi tantangan MEA tahun 2015 ini dengan membuka kesempatan seluasluasnya bagi advokat asing yang akan berpraktik di Indonesia, melalui 7 initial offer, berikut juga tantangan 10 negara ASEAN dalam Business Services. Professional services yaitu (legal services). Menjadi tantangan bersama, adalah Pasal 23 UU Advokat secara tidak langsung menjadi hambatan liberalisasi jasa advokat di Indonesia.

Menjadi perhatian saat ini adalah pendirian kantor hukum oleh advokat asing di Indonesia dengan merekrut para advokat lokal. Namun, ini pun tidak menjadi persoalan, sebab, akan sulit bagi lawyer asing untuk membuat kontrak dalam bahasa Indonesia ${ }^{29}$. Pembatasan advokat asing boleh dibilang tidak bijaksana dalam mengahadi MEA ini, sebab, pembatasan tersebut akan membuat advokat lokal terasing dalam konteks keilmuan, skill, dan networking. Juga, fee

\footnotetext{
${ }^{28} \mathrm{http}: / /$ www.rmol.co/read/2012/01/20/52515/47-Advokat-Asing-Sudah-Berkantor-DiIndonesia- (terakhir diakses 13 September, 2016).

${ }^{29}$ http://badan-huku-m.blogspot.co.id/2013/07/jika-jasa-advokat-juga-diliberalisasi.html (terakhir diakses 13 September, 2016).
} 
yang selama ini masih dalam tataran lokal, tidak dapat mengimbangi fee dalam tataran liberalisasi. Meskipun apa yang sudah kami sampaikan dalam sub bab B.1 tersebut diatas, sesuai dengan Pasal 21 UU Advokat, besaran fee advokat ditetapkan secara wajar berdasarkan persetujuan kedua belah pihak, yang besarannya sekitar 5 sampai 20 persen.

Dengan masuknya MEA dan dengan dibukanya sektor jasa legal service oleh advokat asing, tentunya akan membuka celah dan peluang naiknya fee advokat. Liberalisasi fee advokat, sekalipun merujuk pada kesepakatan sebagaimana juga terdapat dalam Pasal 1320 KUHPerdata, tentunya ada regulasi lain yang perlu dibuat sebagai amanah adanya kepastian dan perlidungan bagi advokat itu sendiri ataupun bagi kliennya. Terlebih, jika advokat Indonesia menerima klien dari negara anggota ASEAN, yang langsung ataupun tidak langsung bersentuhan dengan hukum Indonesia. Disinilah peran pentingnya regulasi pendukung masuknya sektor jasa hukum menghadapi masyarakat MEA.

Sepantasnya pembatasan akan adanya advokat asing sudah mulai dipikirkan lagi untuk dilepas, secara tidak langsung adanya pembatasan tersebut, justru disalahgunakan oleh advokat asing yang berpraktik di Indonesia selama ini yang tentunya merugikan pemerintah Indonesia. Semisal, Pertama, pemberian jasa hukum terhadap pelaku usaha (investor asing) dapat dilakukan secara on project or on case basis, sehingga advokat asing dapat melakukan pekerjaan di Indonesia tanpa harus tinggal atau membuka cabang kantor hukumnya di Indonesia. Misalnya, advokat asing datang ke Indonesia pagi, kemudian sore atau keesokan harinya telah kembali lagi ke negaranya. Praktik seperti ini diduga telah lama terjadi tetapi akan sangat sulit diketahui, kecuali ada pihak yang secara sengaja melaporkan tindakan pemberian jasa hukum oleh advokat asing sebagai tindakan melanggar Pasal 23 UU Advokat. Kedua, dengan adanya perkembangan teknologi dan komunikasi telah mengakibatkan hampir tidak ada lagi jarak dan batas antar wilayah negara, sehingga pemberian jasa hukum oleh advokat asing dapat dilakukan melalui pengunaan alat telekomunikasi yang canggih, misalnya 
rapat secara online, telekonperensi atau dengan teknologi skype. Ketiga, pengertian dari tidak dapat berpraktek secara langsung, dan tidak dapat membuka perwakilan di Indonesia bagi advokat atau lawyer asing, sangat kabur maknanya bila dihadapkan dengan fakta-fakta yang telah lama hadir di Indonesia, dimana kolaborasi dari advokat asing dengan kantor-kantor hukum Indonesia hanya seakan-akan "terlihat" merupakan hubungan pemberi kerja dengan pekerja atau tenaga ahli (employers dengan employees atau foreign legal expert) tetapi terlihat sebagai hubungan partnership, apalagi dengan ketidakjelasan dari makna terminologi dari "in association with."

Contoh-contoh tersebut pada dasarnya hanya memberikan kerugian bagi Indonesia, karena peristiwa semacam itu dapat mengakibatkan peletakan batas pertanggungjawaban profesi menjadi sangat tidak jelas. Aktivitas advokat asing dengan menggunakan strategi yang disebutkan pada angka 1 dan angka 2 di atas, jelas akan lebih merugikan Indonesia. Sebab, selain advokat asing tersebut tidak membayar kewajiban pajak terhadap setiap penghasilan yang telah diperolehnya dari pemberian jasa hukum di Indonesia tersebut, kewajibankewajiban untuk melakukan sharing of knowledge,sharing of business cooperation dan kewajiban untuk melakukan pelayanan masyarakat sehubungan dengan access to justice secara cuma-cuma atau probono menjadi hampir tidak mungkin dilakukan.

Selain itu, perwujudan pasar tunggal ASEAN dengan semangat 'one identity, one destiny' akan mengakibatkan kata 'asing' akan mengalami pengaburan arti dalam wilayah MEA yang dalam Pasal 35 dan 36 The ASEAN Charter telah dibagun dalam identitas tunggal ASEAN, dengan motto: One Vision, One Identity, One Community. Pergerakan jasa hukum secara cross-border akan semakin tidak dapat dihindarkan sebagai bagian dari target free movement of service yang melekat erat dengan aktivitas investasi, produksi dan pemasaran di wilayah ASEAN sebagai konsekuensi dari collective agreements negara-negara anggota ASEAN. Dari sinilah, terlihat bahwa Indonesia atau organisasi advokat Indonesia mau tidak 
mau-suka tidak suka harus membuka batasan-batasan bagi masuknya advokat asing tersebut, sebagai kosekuensi dari disepakatinya masyarakat MEA. Dengan demikian liberalisasi fee advokat menjadi tertukur, transparan dan akuntabel.

\section{Penutup}

Peluang dalam memanfaatkan ASEAN Economic Community 2015 pada perdagangan barang, jasa, investasi dan tenaga kerja cukuplah besar. Perdagangan jasa hukum (legal service) tidak akan mudah dilaksanakan sesuai dengan agenda aksi ASEAN Economic Community karena dengan Pasal 23 UU Advokat Jo. Keputusan Presiden RI No. 75 Tahun 1995 tentang Pembatasan Penggunaan Tenaga Kerja Warga Negara Pendatang Jo. Kemenkumham No. M.11-HT.04.02 Tahun 1997 dan 2004, kedudukan dan peran advokat asing di Indonesia sangat dibatasi. Oleh karena itu, selaras dengan kebijakan Departemen Perdagangan dengan membuka 7 initial offer dan kesepakatan 10 negara ASEAN dalam membuka Business Services-Professional services yaitu (legal services), dan dengan konsep-konsep pentingnya liberalisasi sektor perdagangan, khususnya sektor jasa oleh Talcott Parson dan Adam Smith. Maka Pasal 23 UU Advokat menjadi hambatan bagi liberalisasi jasa advokat.

Dengan adanya kebijakan hukum tentang pembatasan advokat asing di Indonesia, secara langsung atau tidak langsung, Indonesia dirugikan dengan adanya beberapa advokat asing yang berpraktik di Indonesia dengan melakukan kerjasama pembukaan law firm dengan advokat lokal. Kerugian tersebut antara lain: Pertama, praktik advokat asing yang selama ini dilakukan secara on project or on case basis, menyebabkan advokat asing tersebut dapat melakukan pekerjaan tanpa harus tinggal di Indonesia. Kedua, perkembangan teknologi dan komunikasi telah mengakibatkan pemberian jasa hukum oleh advokat asing dapat dilakukan melalui pengunaan alat telekomunikasi; Ketiga, menyebabkan kaburnya pengertian "berpraktik secara langsung, dan tidak dapat membuka perwakilan di Indonesia". Konsekuensinya adalah advokat lokal tidak lagi dapat berpartner 
secara transparan dan tidak mendapatkan kesempatan "share of knowledge" secara langsung dari advokat asing.

Dengan demikian, Liberalisasi fee yang selama ini sekitar 5 sampai 20 persen tidak akan mengalami perubahan. Oleh karenanya, untuk mengimplementasikan ASEAN Economic Community 2015 dalam sektor legal service dan untuk menciptakan perlindungan hukum bagi advokat lokal ataupun klien, sudah menjadi keharusan bagi Pemerintah Indonesia untuk membuka peluang masuknya advokat asing berpraktiik di Indonesia sebagai kompetitor bagi advokat lokal dan sudah tidak masanya lagi membungkus 'perlindungan advokat lokal' dengan mengemas dalam pasal-pasal dalam UU Advokat.

\section{Daftar Pustaka}

Buku

Agus Budianto dan Gwendolyn I. U., Aspek Jasa Pelayanan Kesehatan dalam Prespektif Perlindungan Pasien, Karya Putra Darwati, Bandung, 2010.

FX Joko Priyono, Hukum Perdagangan Jasa Dalam GATS/WTO, Badan Penerbit Universitas Diponegoro, Semarang, 2010.

Geza, Feketekuty, Trade in Professional Services: An Overview, The University of Chicago Legal Forum, Chicago, 1996.

Hadi Soesastro, et., all, Pemikiran dan Permasalahan Ekonomi di Indonesia dalam Setengah Abad Terakhir: Deregulasi dan Liberalisasi Ekonomi, PT. Kanisius, Jogjakarta, 2005.

Hoekman, Bernard M. dan M. Koestecki, Michel, The Political Economy of The World Trading System from GATT to WTO, Oxford University Press, Oxford, 1995.

M. P. Pangaribuan, Advokat dan Contempt of Court Suatu Proses di Dewan Kehormatan Profesi, Penerbit Djambatan, Jakarta, 1996.

Mahmul Siregar, Perdagangan Internasional dan Penanaman Modal, Sekolah Pascasarjana Universitas Sumatera Utara, Medan, 2005

Munir Fuady, Profesi Mulia, PT Citra Aditya Bakti, Bandung, 2005.

Satjtipto Rahardjo, Sisi-Sisi Lain Hukum Di Indonesia, Penerbit Buku Kompas, Jakarta, 2003.

Talcott Parson Today, His Theory and Legacy Contemprorary Sociology, Edited: A. Javier Trevino, Rowman\&Litlle Field Publishers, England, 2001. 


\section{Non Buku}

IBA Secretariat Note A/WPPS/W/9 (11 September 1996), The Relevance of the Disciplines of the Agreements on Technical Barriers to Trade (TBT) and on Import Licensing Procedures to Article VI.4 of the General Agreement on Trade in Services.

UNCTAD, Technology, Trade Policy and the Uruguay Round, United Nations, 1990.

WTO Council for Trade in Services, Legal Services, Background Note by the Secretariat, S/C/W/43, 6 Juli 1998.

Sanchita Basu Das (ed.), ASEAN Economic Community Scorecard, (Singapore: Institute of Southeast378378 Asian Studes, 2013).

Adolf Warouw, Perdagangan Jasa Dalam Kerangka WTO Dan GATS. Presentasi pada Pelatihan tentang WTO, GATS dan Domestic Regulation, (Batam, 5 Agustus 2010).

WTO Council for Trade in Services, Legal Services, Background Note by the Secretariat, S/C/W/43, 6 Juli 1998.

Yenti Gamasih, hukum online: 23 Feb 2005 dalam Jurnal Yustlsla Edisi Nomor 75 Sept-Desember2008 "Legal Service Fee Penasehat Hukum Terdakwa Money Laundering Dalam Sinkronisasi UU Advokat Dan UU Tindak Pidana Pencucian Uang".

Binziad Kadafi, Cs., Advokat Indonesia Mencari Legitimasi Suatu Studi Tentang Tanggungjawab Profesi Hukum di Indonesia, Kata Pengantar Daniel S. Lev, Pusat Studi Hukum dan Kebijakan, Jakarta, 2001

R. Herlambang Perdana, Strategi Pemenuhan Hak Ekosob Di Jatim, Kompas 21 Februari 2006.

\section{Peraturan Perundang-Undangan}

Undang-Undang R.I., No. 18 Tahun 2003, Advokat, L.N.R.I. Tahun 2003 No. 49.

Keputusan Presiden R.I., No. 75 Tahun 1995, Pembatasan Penggunaan Tenaga Kerja Warga Negara Pendatang.

Keputusan Menteri Kehakiman R.I., No. M.01-HT.04.02 Tahun 1997, Penggunaan Ahli Hukum Warga Asing oleh Kantor Konsultan Hukum Indonesia.

Keputusan Menteri Hukum dan Hak Asasi Manusia R.I., No. M.11-HT.04.02 Tahun 2004, Persyaratan dan Tata Cara Memperkerjakan Advokat Asing serta Kewajiban Memberikan Jasa Hukum Secara Cuma-Cuma kepada Dunia Pendidikan dan Penelitian Hukum.

Declaration on the ASEAN Economic Community Blueprint 2007.

\section{Internet}

http://www.mitrahukum.org/publikasi/opini/bantuan-hukum-dalam-perspektiftanggungjawab-negara/

http://www.hukumonline.com/klinik/detail/lt4f0acb102f02e/fee-yang-wajaruntuk-advokat-success-fee-.

http://asean.fta.govt.nz/liberalising-trade-in-services/. 
http://www.rmol.co/read/2012/01/20/52515/47-Advokat-Asing-SudahBerkantor-Di-Indonesia-.

http://badan-huku-m.blogspot.co.id/2013/07/jika-jasa-advokat-jugadiliberalisasi.html. 